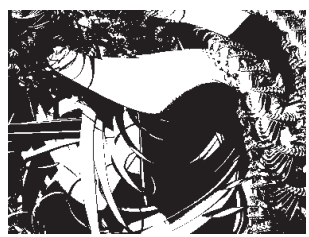

\title{
ODNOS POLITIČKE KORUPCIJE I JAVNIH INVESTICIJA - SLUČAJ HRVATSKE
}

Marijana BAĐUN

Institut za javne financije, Zagreb

UDK: 343.352(497.5):330.322

$$
\begin{aligned}
& 32(497.5): 343.352 \\
& 330.322 .14(497.5): 343.352
\end{aligned}
$$

Izvorni znanstveni rad

Primljeno: 17. 7. 2009.

Cili je ovoga rada pokazati moguće učinke političke korupcije na javne investicije, s posebnim osvrtom na Hrvatsku. $\mathrm{Na}$ početku rada promatra se korelaciju između javnih investicija i korupcije u zemljama Europske unije. Potom se prelazi na slučaj Hrvatske, pri čemu se razmatra kvaliteta infrastrukture, veličina kapitalnih javnih rashoda, nepravilnosti u javnoj nabavi, uloga države u sektoru građevinarstva i učinci političke korupcije na javne kapitalne projekte. Rad pokazuje da zemlje s visokim javnim investicijama imaju i veću (političku) korupciju. Unatoč visokom udjelu javnih kapitalnih rashoda u BDP-u, Hrvatska ima infrastrukturu koja je u lošem stanju. Sudeći po veličini i strukturi javnih investicija te slabim mehanizmima kontrole, u Hrvatskoj na području javnih kapitalnih projekata postoji dosta prilika za političku korupciju, za koje postoje jake indicije da se i iskorištavaju. Umjesto u nove, vrlo vidliive, projekte, nositelii vlasti trebali bi usmieriti više pozornosti i novca u održavanje i pobolišanje postojeće infrastrukture, jer u Hrvatskoj milijarde kuna metaforički i doslovno otječu. Fokusiranje na suzbijanje političke korupcije imalo bi znatne učinke na racionalizaciju proračunskih rashoda i na ekonomski rast.

Ključne riječi: korupcija, javne investicije, infrastruktura, Hrvatska

$\triangle$ Marijana Bađun, Institut za javne financije, Smičiklasova 21, 10000 Zagreb, Hrvatska. E-mail: marijana.badjun@iif.hr

\section{UVOD}

U Hrvatskoj je težište borbe protiv korupcije na administrativnoj ili lakoj / sitnoj korupciji (liječnici, profesori, službenici u zemljišniku itd.), dok pomaka na suzbijanju političke ko- 
DRUŠ. ISTRAŽ. ZAGREB GOD. 20 (2011)

BR. 2 (112),

STR. $295-316$ ODNOŚ POLITIČKE.
BAĐUN, M.:

rupcije gotovo da i nema. Uspješna antikorupcijska iskustva pokazuju kako je ključno da se dokaže krivnja za korupciju visokorangiranih dužnosnika i da ih se, naravno, kazni. Ako se za odgovornost prozovu oni koji su krivi za političku korupciju, onda to povećava vjerodostojnost svih antikorupcijskih programa i pojačava javnu potporu. No ako su optužene "velike zvjerke", a nije ih moguće pravomoćno osuditi, onda se pokušaj suzbijanja korupcije obija o glavu jer potvrđuje da su moćni nedodirljivi. Javnost uzvraća bijesom, nepovjerenjem, apatijom i cinizmom, a upravo je takav bio odgovor građana Hrvatske na vladinu kampanju "Korupcija, to nisam ja".

Cilj je ovoga rada pokazati moguće učinke političke korupcije na javne investicije. Naime, ekonomisti i nositelji vlasti često naglašavaju pozitivan učinak javnih kapitalnih rashoda na ekonomski rast, pritom ne uzimajući u obzir poremećaje koje u taj odnos unosi korupcija. Na početku ovoga rada općenito se opisuje odnos javnih investicija i političke korupcije, a nakon toga promatra korelacija između javnih investicija i korupcije u zemljama Europske unije. Potom se prelazi na slučaj Hrvatske, pri čemu se razmatra kvaliteta infrastrukture, veličina kapitalnih javnih rashoda, nepravilnosti u javnoj nabavi, uloga države u sektoru građevinarstva i učinci političke korupcije na javne kapitalne projekte. Sudeći po veličini i strukturi javnih investicija, lošem stanju infrastrukture, nepravilnostima u javnoj nabavi, velikoj ulozi države u građevinskom sektoru te slabim mehanizmima kontrole, $\mathrm{u}$ Hrvatskoj na području javnih kapitalnih projekata postoji dosta prilika za političku korupciju, za što postoje jake indicije da se i iskorištavaju.

\section{JAVNE INVESTICIJE I POLITIČKA KORUPCIJA}

Politička ili visoka korupcija razlikuje se od birokratske korupcije po tome što su njezini nositelji državni dužnosnici ili visoko rangirani državni službenici. Ona se javlja na najvišim državnim razinama i uključuje velike državne projekte i programe koji znatno utječu na proračun, ali i na perspektivu ekonomskoga rasta neke zemlje. Politička korupcija, između ostalog, unosi poremećaje u proces odlučivanja o javnim investicijskim projektima. Istraživanje koje su proveli Tanzi i Davoodi (1997.) pokazuje da je politička korupcija povezana s većim udjelom javnih investicija u BDP-u, kao i da zemlje s većom političkom korupcijom troše relativno manje na održavanje te imaju lošiju infrastrukturu. ${ }^{1}$ Osim toga, korupcija smanjuje produktivnost investicija, odnosno količinu dodane vrijednosti koja nastaje iskorištavanjem toga kapitala. 
DRUŠ. ISTRAŽ. ZAGREB GOD. 20 (2011), BR. 2 (112)

STR. $295-316$

BAĐUN, $M$. ODNOS POLITIČKE...
Korumpirani nositelji vlasti preferiraju kapitalno-intenzivne javne projekte, jer je kod takvih projekata lakše ubrati mito. Nadalje, visoka potrošnja na projekte koji su vrlo vidljivi, poput cesta, mostova, aerodroma, sportskih stadiona itd., može zbog proračunskih ograničenja ići nauštrb manje atraktivnih rashoda na održavanje ili pak onih na obrazovanje ili zdravstvo (pri čemu se ne misli na nabavu medicinskih uređaja visoke tehnologije, nego na zapošljavanje novih liječnika), u kojima je ujedno teže ubrati mito. Nerijetko to budu grandiozni projekti koji nemaju pozitivan utjecaj na ekonomski razvoj. Štoviše, može biti riječ o projektima koji imaju vrlo malu ili nikakvu ekonomsku opravdanost. Korumpirani vladari podržavat će projekte i politike kojima treba dugi rok za ostvarivanje društvenih neto koristi (Rose-Ackerman, 1999.). Primjerice, veliki građevinski projekti nositeljima vlasti omogućuju mito u sadašnjosti, a istodobno ih ne čine odgovornima za buduće troškove zbog npr. loše izradbe ili visoke zaduženosti.

Poduzeće koje želi dobiti određeni posao od države može platiti mito za dobivanje povjerljivih informacija (npr. prosječne cijene ponude), zatim da se javni natječaj sastavi tako da samo to poduzeće bude kvalificirani ponuditelj, zato da bude izabrano za pobjedničkog ugovaratelja ili zato da se nakon dobivenog ugovora može škrtariti na kvaliteti i/ili "napuhivati" troškove. Mogućnosti manipulacije javnim natječajima brojne su. Kad je visina provizije koju dobivaju dužnosnici vezana uz troškove projekta, može doći do veće sklonosti golemim projektima - korupcija povećava broj investicijskih projekata te povećava njihovu veličinu i složenost. Recimo, može se preferirati cesta sa četiri traka, umjesto sa dva. Nekoliko postotaka u projektu koji stoji milijarde stvara znatan iznos. Poduzeću nije teško pokriti trošak provizije; ponuda za javni natječaj već može sadržavati taj trošak ili može postojati dogovor s državnim ugovarateljem da ponuda bude niska, ali da se to kroz vrijeme nadoknadi "nepredviđenim" troškovima, ili se može škrtariti na kvaliteti itd. Sve to rezultira skupljim projektima u odnosu na one gdje korupcije nema, a ta razlika ide na trošak poreznih obveznika. Čak i kad projekt prvotno nije skup, ali je loše napravljen, to znači dodatna izdvajanja za buduće popravke, primjerice "krpanje" cesta.

Za razliku od tekućih rashoda, koji su uglavnom zadani prethodnim mandatima (plaće, mirovine, socijalna pomoć, kamate na javni dug), kapitalni rashodi nositeljima vlasti omogućuju visok stupanj diskrecije (Tanzi i Davoodi, 1997.). Oni trebaju odlučiti o veličini proračuna za investicije, o raspodjeli sredstava za kapitalne projekte, o izboru projekta i njegovoj lokaciji, pa tako i o veličini svakoga projekta. U tom 
DRUŠ. ISTRAŽ. ZAGREB

BR. 2 (112),

STR. $295-316$

BAĐUN, M.: GOD. 20 (2011), ODNOŚ POLITIČKE...

procesu neki visoko-pozicionirani pojedinci imaju veliku kontrolu i utjecaj, osobito kad su mehanizmi kontrole nad njima (primjerice državna revizija, državno odvjetništvo, organizacije poput USKOK-a, pravosuđe) slabi. U zemljama raširene korupcije analiza troškova i koristi, odnosno stopa povrata, prestaje biti kriterij za izbor projekata, nego je to iznos mita koji nosi određeni projekt. Kad je korupcija u izboru projekata i izvođača građevinskih radova vrlo izražena, onda nastaju tzv. "katedrale u pustinji". Neki projekti budu gotovi, ali ih se nikad ne rabi. Neki su mnogo veći no što bi trebali biti. Neki su toliko loše kvalitete da zahtijevaju stalne popravke i rade ispod kapaciteta. U tim okolnostima nije nikakvo čudo da kapitalni rashodi nemaju pozitivan utjecaj na ekonomski rast kao što se očekuje. Osim toga, zbog podržavanja previše kapitalnih projekata, što često uključuje zaduživanje, nositelji vlasti mogu stvoriti fiskalne krize.

Literatura o ekonomskim učincima korupcije vrlo je opsežna, no ovdje se usredotočujemo na samo jedan segment: odnos javnih investicija i političke korupcije. Jedan od najcitiranijih radova kad su u pitanju učinci korupcije na ekonomski rast jest Mauro (1995.). Uz to, za ekonomske učinke korupcije preporučuje se vidjeti i Mauro (1998.), Lambsdorff (2007.), de la Croix i Delavallade (2009.) te knjigu koju su uredili Heidenheimer i Johnston (2002.).

\section{JAVNE INVESTICIJE I KORUPCIJA - MEĐUNARODNA USPOREDBA}

Podaci koji omogućuju međunarodnu usporedbu s uključenom Hrvatskom odnose se na 2007. godinu, i to na udio neto stjecanja nefinancijske imovine (nabava - prodaja) u BDP-u. Prosjek za EU-27 iznosi 1,7\% (IMF, 2009.) dok se iz grafikona 1 vidi da od prosjeka najviše odudaraju Latvija (5,3\%), Bugarska $(4,9 \%)$, Hrvatska (4\%), Cipar (3,9\%) i Estonija (3,7\%). Dakle, osim Hrvatske, riječ je o novim članicama Europske unije. Njihovi indeksi percepcije korupcije (CPI) za 2007. godinu iznosili su redom: 4,8; 4,1; 4,1; 5,3 i 6,5.2 Znači, u Hrvatskoj i u Bugarskoj je među spomenutim zemljama po percepcijama javnosti korupcija bila najraširenija, a slijedila ih je Latvija. Nažalost, ne postoji indeks koji mjeri samo političku korupciju.

Važno je napomenuti da udio stjecanja nefinancijske imovine $\mathrm{u}$ BDP-u varira po godinama, pa su tako, primjerice, 2005. godine od prosjeka najviše odstupale Malta, Grčka, Portugal, Luksemburg i Hrvatska. Variranja su razumljiva jer empirijska istraživanja pokazuju kako visina javnih investicija ovisi o stopi rasta BDP-a, kretanju javnoga duga, trendovima u veličini deficita, fiskalnoj održivosti itd. (Mehrotra i Välilä, 2006.). Politička korupcija samo je jedna od mogućih odredni- 


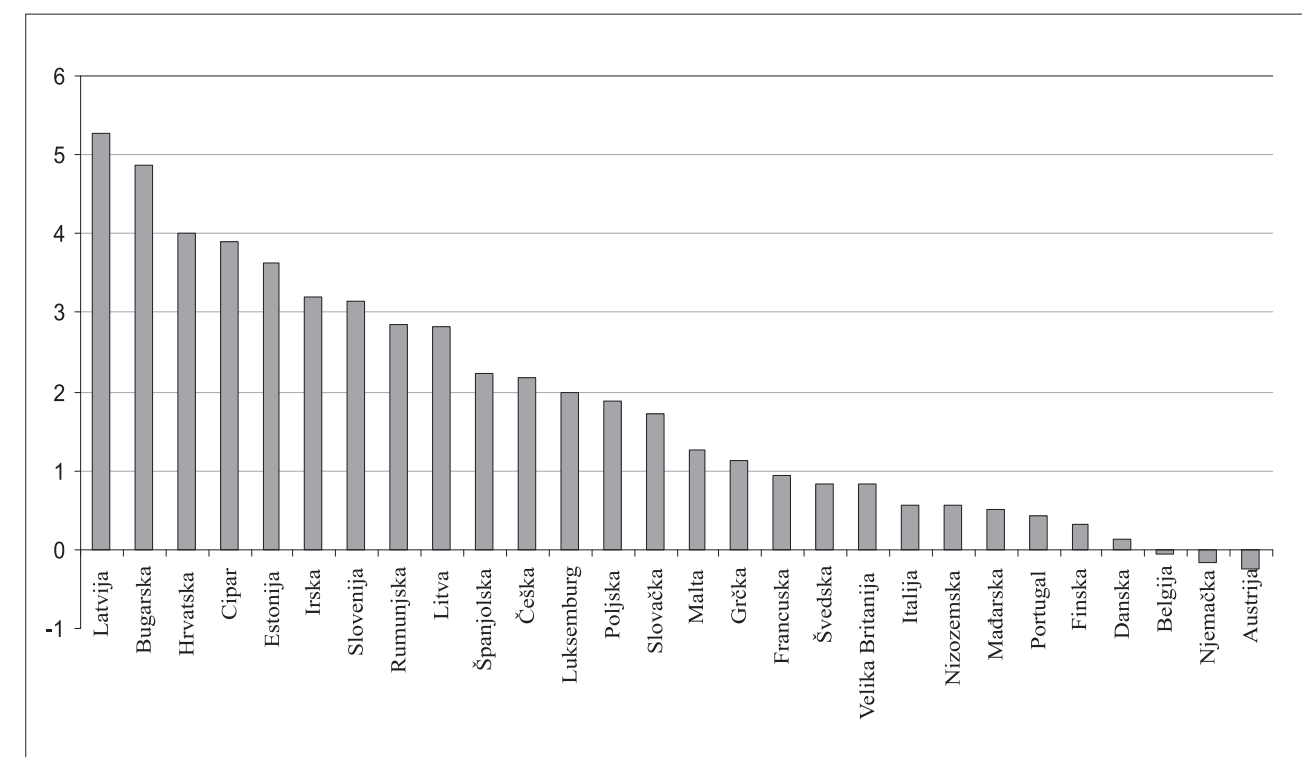

(1) GRAFIKON

Udio neto stjecanja nefinancijske imovine opće države u BDP-u (\%) u 2007. godini prema metodologiii GFS 2001)
* Podaci za Belgiju, Rumunjsku i Sloveniju odnose se na 2006. godinu. Izvor: IMF (2009.)

Na grafikonu 2 vidi se da postoji negativna korelacija (koeficijent korelacije -0,58) između udjela neto stjecanja nefinancijske imovine u BDP-u i indeksa percepcije korupcije. Drugim riječima, što je veći udio neto stjecanja nefinancijske imovine, to je indeks niži, odnosno korupcija veća. To podržava tezu navedenu na početku ovoga rada: zemlje s većom (političkom) korupcijom imaju veće javne investicije. Ujedno vrijedi da u prosjeku razvijenije zemlje imaju nižu korupciju i manji udio neto stjecanja nefinancijske imovine u BDP-u. Korelacija, naravno, ne podrazumijeva i uzročnost; korupcija može povećati javne investicije, ali isto tako i veće investicije stvaraju više prilika za korupciju. U ovom se poglavlju utvrđuje samo smjer i jačina korelacije; utvrđivanje statističkoga smjera kauzalnosti zahtijevalo bi složeniju analizu i bolje raspolaganje podacima.

Nažalost, nisu dostupni međunarodno usporedivi podaci o javnim rashodima na održavanje, kako bi se provjerilo imaju li zemlje s raširenom korupcijom manje rashode za održavanje. Kao zamjensku varijablu za rashode na održavanje istraživači su rabili udio rashoda na zaposlene $u$ ukupnim tekućim rashodima zato što su nositelji vlasti često skloni povećati plaće, a smanjiti izdatke za održavanje. Prema tome, porast udjela plaća može se protumačiti kao pad udjela održavanja. Kasnije ćemo provjeriti kakva je u tom smislu situacija u Hrvatskoj. 


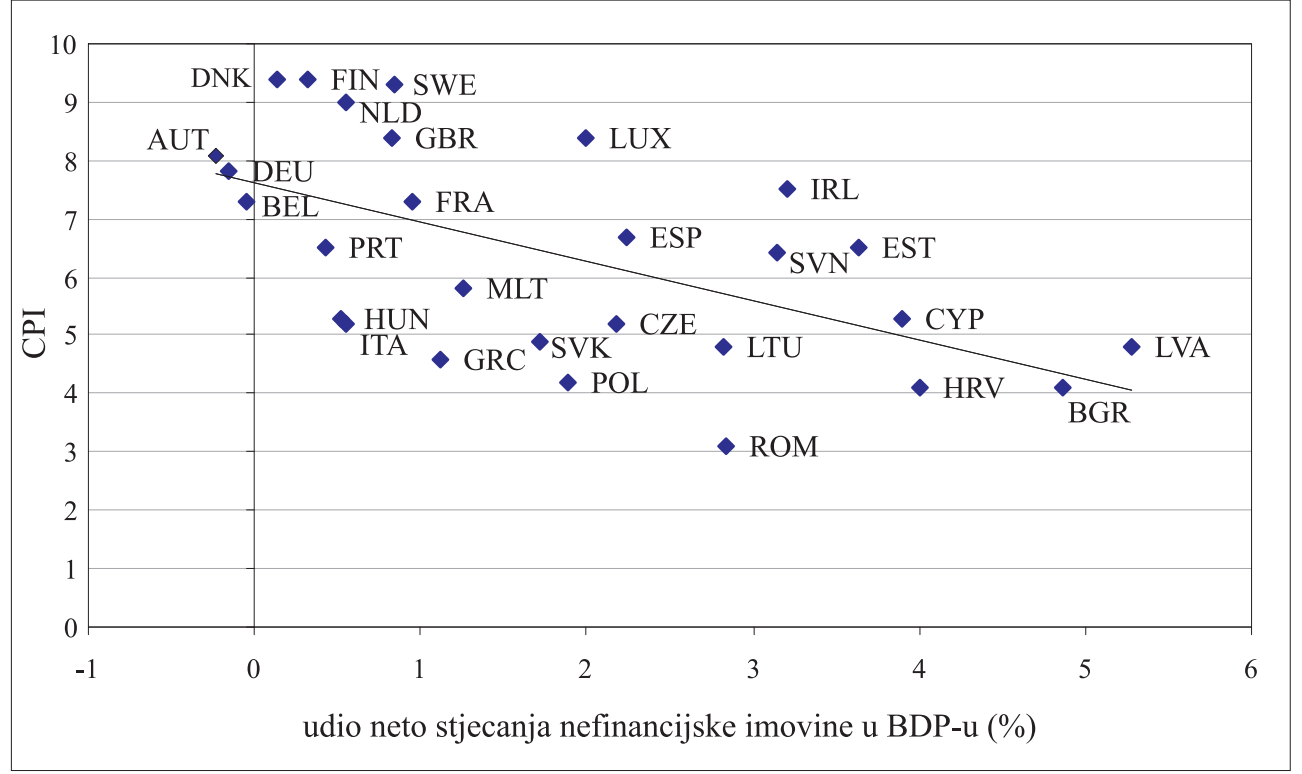

* Podaci za Belgiju, Rumunjsku i Sloveniju odnose se na 2006. godinu. Izvor: IMF (2009.) i TI (2009.)

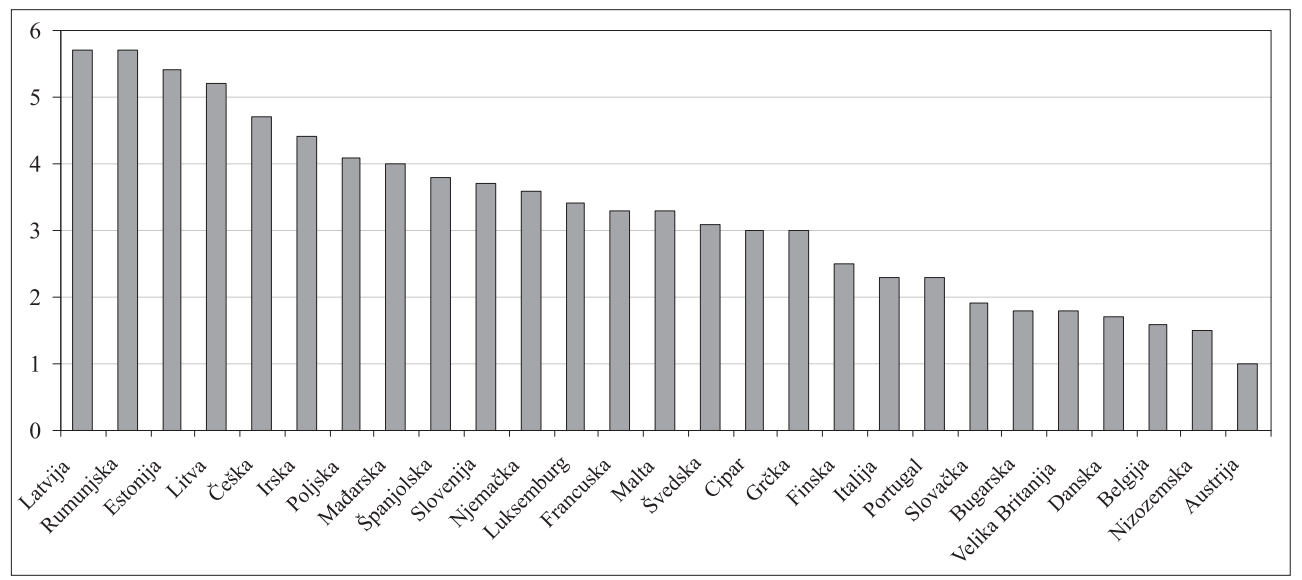

Dก GRAFIKON 2

Odnos između neto stjecanja nefinancijske imovine opće države i korupcije u 2007.

godini

(1) GRAFIKON 3

Udio javnih investicija u BDP-u 2007. godine (prema metodologiii ESA 95)
Izvor: Eurostat (2009.)

Veličina investicija opće države (udio u BDP-u) ponešto se razlikuje po ESA 95 metodologiji iz nacionalnih računa (Eurostat podaci) od GFS 2001 metodologije (MMF podaci). ${ }^{3}$ Ta se razlika vidi iz usporedbe grafikona 1 i 3; 2007. godine udjele veće od 5\% BDP-a imale su Latvija, Rumunjska, Estonija i Litva, dok je EU-27 prosjek iznosio 2,5\%. Nažalost, nema podataka za Hrvatsku. U svakom slučaju, očito je da opet od prosjeka najviše odstupaju nove članice EU-a, pri čemu ovdje dominiraju baltičke zemlje. Među starim zemljama članicama, uzimajući oba izvora podataka, najviše javne investicije ima Irska. 
(1) GRAFIKON 4 Odnos između udjela javnih investicija u BDP-u (ESA 95) i korupcije u 2008 godini
Korelacija između indeksa percepcije korupcije i udjela kapitalnih investicija opće države u BDP-u negativna je i prema najnovijim raspoloživim Eurostatovim podacima za 2008. godinu (grafikon 4), ali slabija. Koeficijent korelacije iznosi -0,45. U nastavku slijedi analiza slučaja Hrvatske.

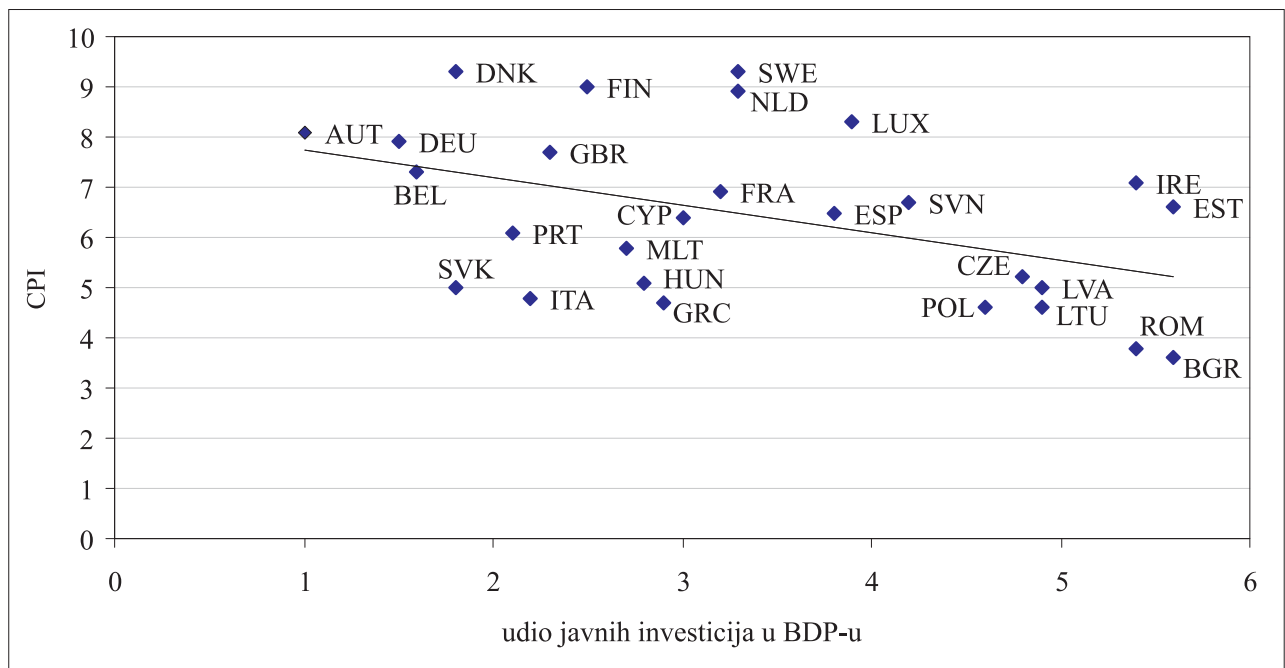

Izvor: Eurostat (2009.) i TI (2009.)

\section{SLUČAJ HRVATSKE}

U ovom dijelu rada pokušat će se promotriti mogući utjecaj političke korupcije na javne investicije u Hrvatskoj. Kako to nije moguće učiniti izravno, zbog neimanja brojčanih podataka o političkoj korupciji, veza će se promatrati neizravno. Pritom će se sagledati kvaliteta infrastrukture, veličina i struktura kapitalnih javnih rashoda, javna nabava, uloga države u građevinskom sektoru i svi ostali eventualni "dokazi" koji upućuju na to da politička korupcija u Hrvatskoj unosi poremećaje u javne investicije.

\section{Kvaliteta infrastrukture}

Već je rečeno da zemlje s visokom političkom korupcijom prosječno imaju infrastrukturu lošije kvalitete zbog slabijeg održavanja. Naime, u zemljama raširene političke korupcije stalno se poduzimaju novi projekti, jer kod njih postoji veća mogućnost ubiranja mita, dok se postojeća infrastruktura ostavlja da propada. Pogledajmo stoga kakva ja situacija u Hrvatskoj, i to na području opskrbe vodom, odvodnje, električne energije te cestovne i željezničke infrastrukture. Naravno, analiza bi se mogla proširiti i na druga područja, ovdje je izabrano tek nekoliko slikovitih primjera. Svako od ovih područja vrlo je kompleksno i ubuduće bi ga trebalo detaljnije istražiti. Ovdje se samo ukratko opisuje sadašnje stanje. 
DRUŠ. ISTRAŽ. ZAGREB GOD. 20 (2011) BR. 2 (112),

STR. $295-316$

BAĐUN, M.: ODNOŚ POLITIČKE...

(1) TABLICA 1

Priključenost stanovništva na kanalizacijski sustav (2007.)

\section{Opskrba vodom}

Hrvatska se nalazi na 5. mjestu u Europi po procijenjenim količinama vode po stanovniku. Međutim, samo 75\% stanovnika ima priključak na vodovodnu mrežu, a sustav opskrbe vodom obilježavaju veliki gubici. Preciznije, u Hrvatskoj se na jedan zahvaćeni kubični metar vode $u$ distribuciji prosječno izgubi oko 40\% vode, dok Europska unija prihvatljivim smatra 15 do $18 \%$ gubitaka (Bajo i Filipović, 2008.). Postoje znatne razlike među županijama, pri čemu je rekorder u gubicima Zadarska županija s čak 68\%, dok kriterije Europske unije zadovoljava samo Koprivničko-križevačka županija s gubicima od tek $8 \%$. Gubici su najčešće rezultat slabog održavanja i investiranja u vodoopskrbnu mrežu. Naravno, ti se gubici odražavaju na financijsko poslovanje komunalnih društava povećava se potreba za transferima iz proračuna lokalnih jedinica, pa cijena vode raste.

\section{Sustav odvodnje}

Priključenost stanovništva na javne sustave odvodnje u 2007. godini u naseljima većima od 10000 stanovnika iznosila je 75 do $80 \%$. Međutim, u naseljima s manje od 2000 stanovnika, u kojima živi oko $40 \%$ populacije, priključak na kanalizacijski sustav imalo je samo 6\% stanovnika (Hrvatske vode, 2009.). Gledajući ukupno, 2007. godine u Hrvatskoj je samo 43\% stanovnika imalo priključak na kanalizacijski sustav. Stanje priključenosti po regijama najbolje je na području primorsko-istarskih sljevova (58\%), a najlošije na dalmatinskima (31\%). Od 295 naselja koja imaju izgrađeni kanalizacijski sustav, samo njih $44 \%$ posjeduje i uređaj za pročišćavanje otpadnih voda. Pročišćene otpadne vode zasad se ne iskorištavaju. Osim toga, s obzirom na starost kanalizacijskoga sustava u gradovima, može se pretpostaviti da je većina kanalizacijskih sustava u znatnoj mjeri vodopropusna. Za izgradnju i razvoj sustava javne odvodnje zadužene su lokalne jedinice.

\begin{tabular}{|c|c|c|c|c|c|c|c|c|}
\hline \multirow{3}{*}{$\begin{array}{l}\text { Veličina naselja } \\
\text { (broj stanovnika) }\end{array}$} & \multirow{3}{*}{$\begin{array}{r}\text { Obu- } \\
\text { hvaćeno }\end{array}$} & \multirow{3}{*}{\multicolumn{2}{|c|}{$\begin{array}{r}\text { Broj naselja } \\
\text { Bez kana- } \\
\text { lizacijskog } \\
\text { sustava }\end{array}$}} & \multicolumn{5}{|r|}{ Stanovnici } \\
\hline & & & & \multicolumn{2}{|c|}{ Priključeni } & \multicolumn{2}{|c|}{$\begin{array}{l}\text { Nisu } \\
\text { priključeni }\end{array}$} & \multirow{2}{*}{$\frac{\text { Ukupno }}{\text { Broj }}$} \\
\hline & & & & Broj & $\%$ & Broj & $\%$ & \\
\hline$<2000$ & 1040 & 155 & 885 & 111717 & 6 & 1640828 & 94 & 1752545 \\
\hline $2000-10000$ & 189 & 102 & 87 & 267602 & 37 & 455883 & 63 & 723485 \\
\hline $10000-50000$ & 31 & 31 & 0 & 501527 & 74 & 172036 & 26 & 673563 \\
\hline$>50000$ & 7 & 7 & 0 & 1042126 & 81 & 245741 & 19 & 1287867 \\
\hline Ukupno & 1267 & 295 & 972 & 1922972 & 43 & 2514888 & 57 & 4437460 \\
\hline
\end{tabular}

Izvor: Hrvatske vode (2009.) 
DRUŠ. ISTRAŽ. ZAGREB GOD. 20 (2011), BR. 2 (112)

STR. $295-316$

BAĐUN, $M$ ODNOS POLITIČKE..

2 TABLICA 2

Gubici u prijenosu i distribuciii električne energije (\% ukupne proizvodnje)

\section{Električna energija}

Kad su u pitanju gubici u prijenosu i distribuciji električne energije, podaci su jednako zabrinjavajući kao i kod gubitaka $\mathrm{u}$ distribuciji vode - osobito kad se napravi međunarodna usporedba. Iz Tablice 2 vidi se da Hrvatska prosječno u distribuciji gubi nešto manje od $20 \%$ električne energije, što je znatno više u odnosu na članice Europske unije, s iznimkom Latvije. Primjerice, Luksemburg bilježi drastično smanjenje gubitaka, pa sad oni iznose samo 3\%. Najbolje rezultate među bivšim socijalističkim zemljama imaju Slovenija (6\%), Češka $(6 \%)$ i Slovačka $(5 \%)$.

1999. 2000. 2001. 2002. 2003. 2004. 2005.

\begin{tabular}{lrrrrrrr}
\hline Austrija & 6 & 6 & 6 & 5 & 6 & 6 & 5 \\
Belgija & 5 & 5 & 5 & 5 & 4 & 5 & 5 \\
Bugarska & 17 & 15 & 14 & 15 & 14 & 12 & 11 \\
Cipar & 6 & 6 & 7 & 4 & 4 & 5 & 4 \\
Češka & 8 & 7 & 7 & 6 & 6 & 6 & 6 \\
Danska & 5 & 6 & 6 & 5 & 4 & 4 & 4 \\
Estonija & 18 & 15 & 16 & 15 & 12 & 11 & 11 \\
Finska & 4 & 4 & 4 & 4 & 4 & 3 & 4 \\
Francuska & 6 & 6 & 6 & 6 & 6 & 6 & 6 \\
Grčka & 7 & 8 & 9 & 7 & 9 & 9 & 9 \\
Hrvatska & 17 & 19 & 20 & 17 & 20 & 17 & 17 \\
Irska & 8 & 9 & 8 & 8 & 8 & 8 & 8 \\
Italija & 7 & 7 & 7 & 7 & 7 & 7 & 7 \\
Latvija & 27 & 24 & 23 & 25 & 23 & 19 & 17 \\
Litva & 10 & 12 & 10 & 8 & 7 & 7 & 8 \\
Luksemburg & 35 & 33 & 35 & 7 & 6 & 1 & 3 \\
Mađarska & 13 & 14 & 13 & 12 & 12 & 12 & 11 \\
Malta & 12 & 12 & 13 & 13 & 13 & 13 & 11 \\
Nizozemska & 5 & 5 & 4 & 4 & 4 & 4 & 4 \\
Njemačka & 4 & 4 & 4 & 5 & 5 & 6 & 5 \\
Poljska & 10 & 10 & 10 & 10 & 10 & 9 & 9 \\
Portugal & 8 & 8 & 9 & 8 & 8 & 9 & 9 \\
Rumunjska & 13 & 13 & 13 & 12 & 9 & 11 & 10 \\
Slovačka & 7 & 6 & 4 & 3 & 6 & 4 & 5 \\
Slovenija & 5 & 6 & 5 & 5 & 6 & 6 & 6 \\
Španjolska & 9 & 9 & 8 & 8 & 9 & 9 & 9 \\
Švedska & 7 & 7 & 7 & 8 & 8 & 7 & 7 \\
Velika Britanija & 8 & 8 & 8 & 8 & 8 & 9 & 8 \\
Prosjek EU-27 & 10 & 10 & 10 & 8 & 8 & 8 & 8 \\
& & & & & & &
\end{tabular}

Izvor: World Bank (2009.)

\section{Cestovna infrastruktura}

Po udjelu asfaltiranih cesta u ukupnim cestama Hrvatska stoji relativno dobro $-85 \%$ cesta je asfaltirano, što nije daleko od $100 \%$, koliko ima manje od polovice članica Europske unije (World Bank, 2009.). Međutim, kad se pogleda stanje posto- 
DRUŠ. ISTRAŽ. ZAGREB GOD. 20 (2011) BR. 2 (112),

STR. $295-316$

BAĐUN, M.: ODNOS POLITIČKE..

GRAFIKON 5 Stanje državnih cesta (2005.) jećih kolnika, što upućuje na to koliko se ulaže u održavanje, podaci nisu toliko dobri. Naime, 2005. godine gotovo 50\% državnih cesta (kolnika) bilo je u lošem ili u vrlo lošem stanju, a manje od trećine $\mathrm{u}$ dobrom i vrlo dobrom stanju (grafikon 5). Za njihovo održavanje zadužene su Hrvatske ceste, dok županijske uprave za ceste upravljaju županijskim i lokalnim cestama. Oko $50 \%$ mreže tih cesta nalazi se u lošem stanju, pri čemu je na $10 \%$ cesta površina kolnika oštećena više od $80 \%$. Programom građenja i održavanja javnih cesta od 2005. do 2008. godine bilo je planirano povećanje rashoda na održavanje, ali podataka o učincima toga programa u smislu kvalitete postojećih cesta nema. Primjerice, za državne ceste u tom razdoblju namijenjeno je 3,5 milijardi kuna za održavanje, a 4,6 milijardi kuna za investicije. Kod autocesta riječ je o 11,2 milijarde kuna za građenje (od toga 8,7 milijardi kuna kreditnih sredstava), a 2,8 milijardi kuna za održavanje. U održavanju i građenju županijskih i lokalnih cesta značajno sudjeluju Hrvatske ceste, koje su trebale izdvojiti 960 mil. kuna. ${ }^{4}$ Nažalost, Program građenja i održavanja javnih cesta od 2009. do 2012. do kraja 2009. godine još nije donesen.

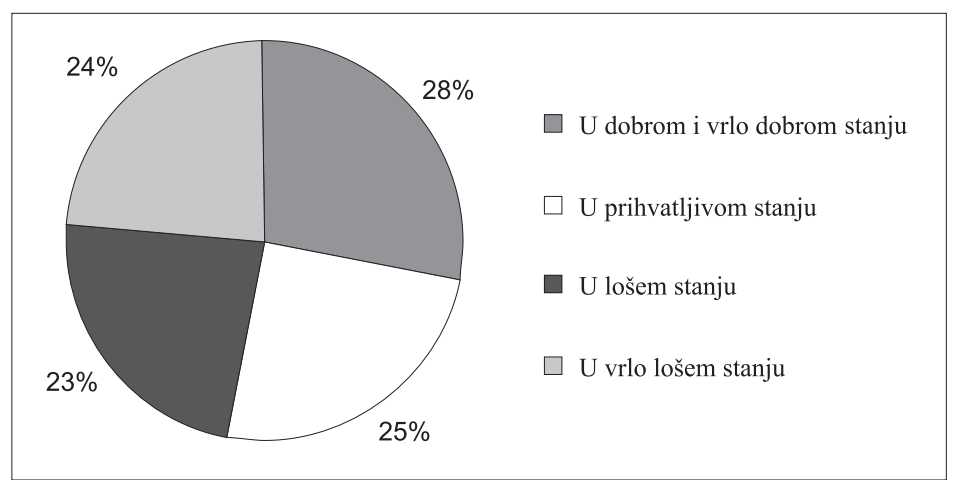

Izvor: Narodne novine (2005.)

\section{Željeznička infrastruktura}

Željeznička infrastruktura u vrlo je lošem stanju po svim pokazateljima, što se vidi iz Nacionalnoga programa željezničke infrastrukture od 2008. do 2012. (Narodne novine, 2008.). Samo je $9 \%$ dvokolosječnih pruga, što ograničuje propusnu i prijevoznu moć, a ukupno je elektrificirano 36\% pruga. Funkcionalnost željezničke mreže zbog starosti i dotrajalosti stalno se pogoršava te se kontinuirano smanjuju dopuštene brzine vlakova. Brzinu vlakova od $160 \mathrm{~km} / \mathrm{h}$ može podnijeti samo $4 \%$ ukupne duljine kolosijeka otvorene pruge, a od $100 \mathrm{~km} / \mathrm{h}$ mršavih $12 \%$. S obzirom na to da je sustav pruga dotrajao, u idućih 5-8 godina moguće je normalno ili pojačano održavati samo $45 \%$ ukupne duljine pruga. Na ostatku treba obaviti velike investicijske radove ili takve pruge zatvoriti za promet. 
DRUŠ. ISTRAŽ. ZAGREB GOD. 20 (2011), BR. $2(112)$

STR. $295-316$

BAĐUN, $M$ ODNOS POLITIČKE...
Kontaktna mreža na elektrificiranim prugama stara je oko 35 godina, a propisani remont mreže svakih osam do deset godina nije se provodio zbog manjka financijskih sredstava. Veći dio kolodvora i otvorene pruge na glavnim željezničkim prugama osiguran je zastarjelim signalno-sigurnosnim uređajima, a manji dio nije uopće osiguran jer su uređaji uništeni u ratu i nisu obnovljeni. Primjerice, signalno-sigurnosni uređaj na Glavnom kolodvoru u Zagrebu star je čak 67 godina. Najveći dio ugrađenih telekomunikacijskih uređaja i opreme stariji je od propisanoga uporabnog vijeka i tehnološki je zastario; kabeli su stari od 25 do 70 godina, a linije više od 70 godina. Automatske telefonske centrale stare su i do 60 godina, a radiodispečerski uređaji 35 godina. Zbog zastarjelosti, dotrajalosti i nepotpunosti, telekomunikacijski sustav na željezničkoj mreži nije pouzdan i ne odgovara zahtjevima suvremenoga željezničkog prometa.

Tehničko stanje lokalnih željezničkih pruga osobito je loše; brzine vlakova pretežno su od 40 do $60 \mathrm{~km} / \mathrm{h}$, a na malen kapacitet utječe i neopremljenost signalno-sigurnosnim uređajima. Planirana ulaganja u osuvremenjivanje i izgradnju te troškovi za održavanje željezničke infrastrukture od 2008. do 2012. okvirno iznose 18 milijardi kuna; 7,7 milijardi kuna za osuvremenjivanje, 4,9 za izgradnju novih pruga i kolosijeka, a 5,4 za održavanje. Gotovo $90 \%$ iznosa za realizaciju treba doći iz državnoga proračuna, a ostatak iz pretpristupnih fondova EU-a i ostalih izvora.

\section{Kapitalni javni rashodi}

Pošto smo vidjeli da je stanje sadašnje infrastrukture $u$ Hrvatskoj loše, pogledajmo koliki su kapitalni javni rashodi. Iz Tablice 3 vidi se da je udio rashoda za nabavu nefinancijske imovine konsolidirane opće države u BDP-u 2007. godine bio visokih 4,5\%, odnosno 12,3 milijarde kuna. ${ }^{5}$ Najveći dio tog iznosa odnosi se na dugotrajnu imovinu, 11,5 milijardi kuna. Iako je udio nabave nefinancijske imovine u BDP-u od 2002. do 2007. godine bio relativno visok, 2008. godine iznosio je 2,6\%, što se može povezati s počecima gospodarske krize. Naime, 2007. godine stopa rasta BDP-a iznosila je 5,5\% , a 2008. godine $2,4 \%$ (HNB, 2009.). U nabavi u svim godinama više od $90 \%$ dominira nabava zgrada i građevina. Pritom najveći udio u toj nabavi imaju izvanproračunski korisnici i agencije, zatim jedinice lokalne i područne (regionalne) samouprave, a najmanji državni proračun. Među izvanproračunskim korisnicima od 2002. do 2007. godine najveći dio imaju Hrvatske ceste i Hrvatske autoceste. Hrvatske autoceste od 2008. godine više nisu izvanproračunski korisnik nego javno poduzeće. Udio neto stjecanja nefinancijske imovine u BDP-u iznosio je 2008. godine $2,1 \% .^{6}$ 


\begin{tabular}{lrrrrrrr}
\hline & 2002. & 2003. & 2004. & 2005. & 2006. & 2007. & 2008. \\
\hline Neto stjecanje nefinancijske imovine & 7.265 & 9.664 & 10.495 & 9.060 & 9.083 & 11.015 & 7.344 \\
$\%$ BDP-a & 4,0 & 4,9 & 4,9 & 3,9 & 3,6 & 4,0 & 2,1 \\
Nabava nefinancijske imovine & 7.917 & 10.398 & 11.360 & 9.924 & 10.350 & 12.319 & 8.877 \\
$\%$ BDP-a & 4,4 & 5,2 & 5,3 & 4,3 & 4,1 & 4,5 & 2,6 \\
Dugotrajna imovina & 7.549 & 10.078 & 10.928 & 9.437 & 9.605 & 11.531 & 7.993 \\
Zalihe & 0 & 0 & 0 & 0 & 1 & 37 & 87 \\
Pohranjene vrijednosti & 72 & 7 & 8 & 7 & 8 & 10 & 10 \\
Neproizvedena imovina & 296 & 313 & 424 & 480 & 736 & 742 & 786 \\
\hline
\end{tabular}

Izvor: Ministarstvo financija (2009.a) i DZS (2008.), izračun autorice

(1) TABLICA 3

Rashodi za nabavu nefinancijske imovine konsolidirane opće države (mil. HRK)
Iz državnog se proračuna 2009. planiralo potrošiti 3,6 milijardi kuna na nabavu nefinancijske imovine, od čega 1,3 milijarde kuna na građevinske objekte (Ministarstvo financija, 2009.b). Međutim, nakon toga uslijedila su čak tri rebalansa proračuna. Zadnjim rebalansom na nabavu nefinancijske imovine planira se utrošiti 2,5 milijardi kuna, od čega 959,8 mil. kuna na građevinske objekte. Dakle, primjetno je smanjenje od 1,1 milijarde kuna za nabavu nefinancijske imovine zbog nepovoljne gospodarske situacije, a time i slabijega punjenja proračuna.

Što se tiče izvanproračunskih korisnika koji su povezani uz raniji opis infrastrukture, Hrvatske ceste nakon triju rebalansa 2009. godine planiraju potrošiti 714,6 mil. kuna (prvotno 1,1 milijardu kuna) na građevinske objekte, a Hrvatske vode 170,5 mil. kuna (prvotno 180,6 milijuna). Kad je riječ o održavanju, iz državnog je proračuna prvotno trebalo biti potrošeno 830,3 mil., Hrvatskih cesta 746 mil., a Hrvatskih voda 1 milijarda kuna. Nakon triju rebalansa riječ je o iznosima od 628,1 mil., 797,2 mil. i 917,7 mil. kuna. Zanimljivo je da je kod Hrvatskih cesta došlo do porasta rashoda na održavanje. Oko $45 \%$ rashoda Hrvatskih voda odlazi na održavanje, a samo oko $8 \%$ na nabavu novih građevinskih objekata, što vjerojatno pokazuje da je vodoopskrbna mreža desetljećima propadala i da su joj sada potrebne nove investicije jer samo održavanje nije dovoljno, osobito kad se uzmu u obzir gubici u distribuciji vode. Slično se može reći i za javno poduzeće Hrvatske željeznice. Hrvatske autoceste od 2008. godine više nisu izvanproračunski korisnik, ali je planom za 2008. bilo predviđeno potrošiti oko 4 milijarde kuna na građenje.

$\mathrm{U}$ Tablici 4 naveden je i udio rashoda za zaposlene radi dobivanja uvida u odnose veličina. Naime, prvotni rashodi za nabavu građevinskih objekata činili su 1,1\% ukupnih rashoda državnoga proračuna (1,3 milijarde kuna), a zaposlene 18,5\% (23,5 milijardi kuna). Nakon rebalansa riječ je o $0,8 \%$ ukupnih rashoda na građevinske objekte (959,8 mil. kuna) te $18,4 \%$ na 
(1) TABLICA 4

Udjeli odabranih stavki proračuna u ukupnim planiranim rashodima za 2009. (\%) zaposlene (22,2 milijarde kuna). Rashodi za održavanje pak čine $0,7 \%$ ukupnih rashoda, prije i nakon rebalansa. Očito je da su rashodi za održavanje izrazito mali u odnosu na rashode za zaposlene.

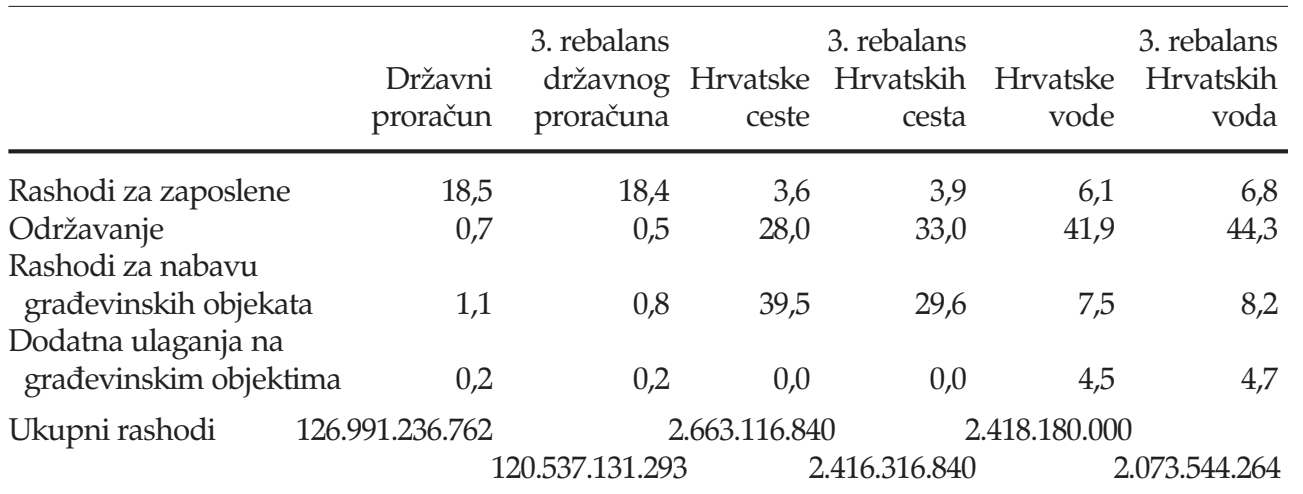

Izvor: Ministarstvo financija (2009.b), izračun autorice

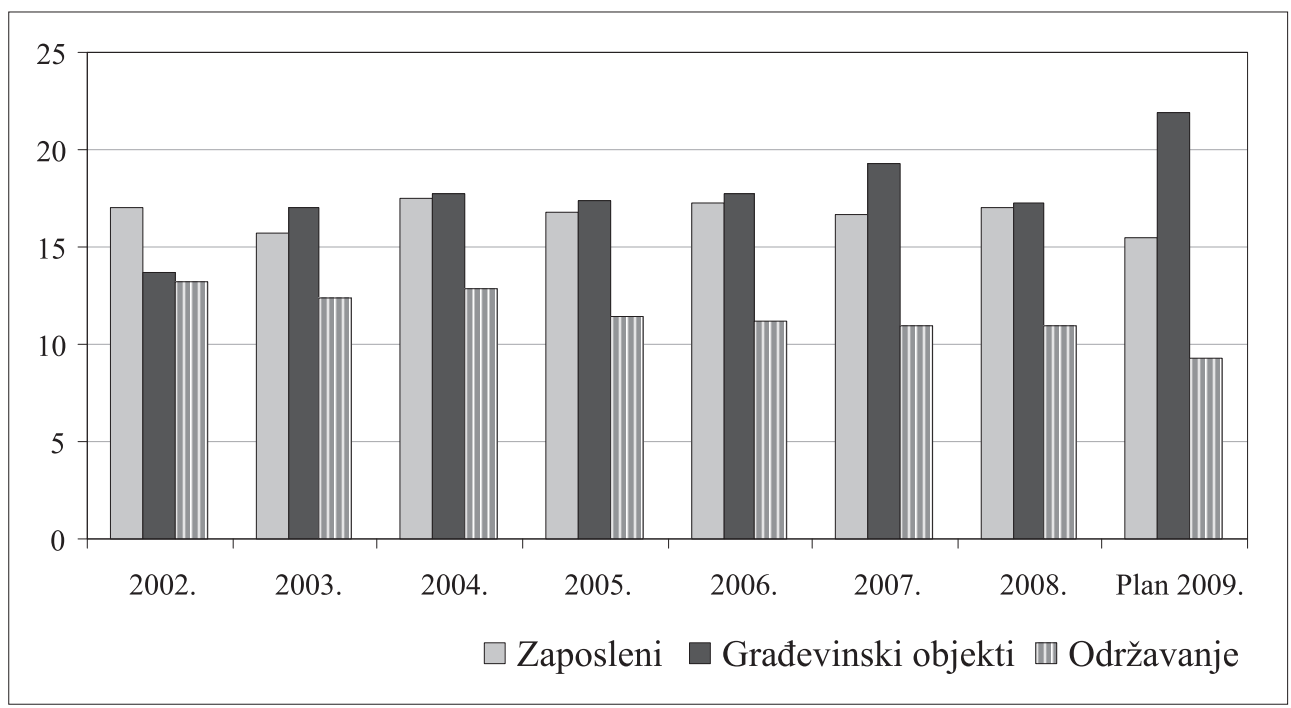

(1) GRAFIKON 6

Udjeli odabranih

stavki proračuna u rashodima lokalnih vlasti (\%)
Izvor: Ministarstvo financija (2009.c), izračun autorice

U lokalnim jedinicama 2008. godine utrošeno je 4,4 milijarde kuna za građevinske objekte, a 2,8 milijardi kuna za održavanje (Ministarstvo financija, 2009.c). Plan za 2009. godinu predviđa 6,8 milijardi kuna za građevinske objekte, a 2,9 milijardi kuna za održavanje. Za dodatna ulaganja na građevinskim objektima predviđa se 888,2 mil. kuna. Iz grafikona 6 vidi se da s vremenom raste udio rashoda za građevinske objekte u ukupnim rashodima, ali da se udio rashoda za održavanje (materijal, dijelovi i usluge za tekuće i investicijsko održa- 
DRUŠ. ISTRAŽ. ZAGREB GOD. 20 (2011)

BR. 2 (112),

STR. $295-316$

BAĐUN, M.: ODNOS POLITIČKE.

\section{Javna nabava}

vanje) smanjuje. Udio rashoda za zaposlene odgovara onomu u državnom proračunu, ali je specifično da udio rashoda za građevinske objekte nadmašuje udio rashoda za zaposlene. Od 2003. godine više od $15 \%$ rashoda lokalne države bilo je namijenjeno građevinskim objektima. Plan za 2009. pokazuje da se želi smanjiti udio rashoda za zaposlene i održavanje, a povećati za građevinske objekte. Kategorija građevinski objekti sadrži stambene objekte, poslovne objekte, ceste, željeznice i slične građevinske objekte te ostale građevinske objekte. U planu za 2009. ostali građevinski objekti čine polovicu svih građevinskih objekata, što je nepovoljno s aspekta transparentnosti potrošnje lokalnih jedinica. Ovdje je važno napomenuti kako je nadzor nad lokalnim proračunima nedovoljan te da su po percepcijama javnosti lokalne vlasti na trećem mjestu po korupciji - iza sudstva i zdravstva. ${ }^{7}$

Kapitalni javni rashodi izravno su povezani sa sustavom javne nabave. U Hrvatskoj u okviru Ministarstva gospodarstva, rada i poduzetništva djeluje Uprava za sustav javne nabave, kojoj je uloga preventivno-instruktivna. Kao kontrolni mehanizam djeluje Državna komisija za kontrolu postupaka javne nabave, ali i Državni ured za reviziju te USKOK i DORH. Za praćenje provedbe Nacionalnoga programa suzbijanja korupcije osnovano je Nacionalno vijeće, a među važnim stavkama koje to vijeće prati jest i javna nabava. Upravo je to Vijeće upozorilo na to da štete za hrvatsko gospodarstvo zbog korupcije u javnim nabavama iznose šest milijardi kuna godišnje. Vrijednost javne nabave u Hrvatskoj iznosila je 2007. godine 44 milijarde kuna, a procijenjena vrijednost za 2008. iznosi 30 milijardi kuna. U 2007. godini podneseno je 637 žalbi Državnoj komisiji, na oko 5\% postupaka javne nabave, od čega je prihvaćeno 269 (DKOM, 2008.). Ukupna vrijednost nabave zaprimljenih žalbenih predmeta iznosila je 4,6 milijardi kuna.

Gledano po pojedinačnim državnim tijelima, najviše se žalbi odnosilo na Zagrebački holding (21), Hrvatske autoceste (18), Splitsko-dalmatinsku županiju (17), HEP - Operator distribucijskog sustava (16) i Ministarstvo mora, turizma i prometa (15). No, u Zagrebačkom je holdingu prihvaćeno samo $10 \%$ žalbi, dok je među spomenutim tijelima najveći postotak prihvaćenih žalbi u Splitsko-dalmatinskoj županiji (65\%) i Hrvatskim autocestama (33\%). Po postotku prihvaćenih žalbi prednjači Državna geodetska uprava (100\%, tj. 5 od 5). Od 2004. godine bilježi se kontinuirani pad broja žalbi. No moguće je da se to događa zbog straha. Naime, ako se tko žali na postupak javne nabave, to mu može otežati daljnje sudjelovanje $u$ javnim natječajima. 
DRUŠ. ISTRAŽ. ZAGREB GOD. 20 (2011), BR. $2(112)$

STR. $295-316$

BAĐUN, $M$ ODNOS POLITIČKE...
Ovdje je važno spomenuti kako Državni ured za reviziju godinu za godinom bilježi nepravilnosti u postupku javne nabave u praktički svim županijama. Europska je komisija pak u svom izvješću za Hrvatsku za 2008. godinu utvrdila da je nužno jačati funkcionalnu neovisnost Državnog ureda za reviziju (European Commission, 2008.). Nažalost, u Izvješću o radu državnih odvjetništava u 2008. godini (DORH, 2009.) ne spominje se izričito javna nabava, nego samo zlouporabe službene dužnosti koje mogu biti različitih vrsta, tako da nema podataka o istragama i optužnicama u slučajevima javne nabave. No u medijima su se 2009. godine spominjale istrage državnog odvjetništva u HŽ-u, HEP-u, Hrvatskim cestama, Hrvatskim autocestama itd., a koje su posredno ili neposredno bile vezane uz javnu nabavu. ${ }^{8}$ Sudske presude još nisu donesene. U svim korupcijskim aferama prenesenim u medijima naslućuje se trag prema najvišim državnim razinama. To ne začuđuje jer su dužnosnici nerijetko članovi nadzornih odbora poduzeća, a i stoga što se kapitalni projekti većinom provode preko javnih poduzeća. Pogledajmo sada koliki je udio države u građevinskom sektoru.

\section{Udio države u građevinskom sektoru}

Prema podacima Državnoga zavoda za statistiku, država ima vrlo veliku ulogu u građevinskom sektoru. Država je 2006. godine bila investitor u gotovo $60 \%$ vrijednosti izvršenih građevinskih radova (Tablica 5). Preciznije, od 21,4 milijarde ukup-

(1) TABLICA 5

Vrijednost izvršenih radova prema vrsti investitora (u milijardama kuna) no izvršenih radova, država je investirala 12,5 milijardi kuna. Riječ je o tijelima državne vlasti i uprave te lokalne uprave i samouprave, kao i javnim poduzećima, ustanovama, fondovima, udrugama i drugim organizacijama.

\begin{tabular}{lrrrrr}
\hline & 2002. & 2003. & 2004. & 2005. & 2006. \\
\hline Pravne osobe & 11,3 & 16,0 & 16,6 & 17,3 & 21,0 \\
Tijela državne vlasti i uprave te lokalne uprave i samouprave & 2,7 & 2,1 & 2,2 & 2,6 & 3,7 \\
Javna poduzeća, ustanove, fondovi, udruge i druge organizacije & 3,1 & 7,1 & 7,4 & 8,0 & 8,8 \\
Ostale pravne osobe & 5,5 & 6,7 & 7,0 & 6,7 & 8,4 \\
Fizičke osobe & 0,2 & 0,2 & 0,3 & 0,5 & 0,5 \\
Ukupno & 11,5 & 16,2 & 16,9 & 17,8 & 21,4 \\
\hline
\end{tabular}

Izvor: DZS (2008.)

Kad se pogleda vrijednost izvršenih radova prema vrsti građevine za 2006. godinu (Tablica 6), najveći udio ima prometna infrastruktura $-40 \%$ (8,5 milijardi). Na cjevovode, komunikacijske i energetske vodove otpada $14 \%$ (3 milijarde), dok nestambene građevine čine $29 \%$ ukupne vrijednosti $(6,1$ milijarda). Ako se vrijednost izvršenih radova promatra prema vrsti radova, onda dominira novogradnja sa $64 \%$, na rekon- 
(1) TABLICA 6

Vrijednost izvršenih radova prema vrsti građevine (u

milijardama kuna) strukcije, adaptacije i velike popravke odlazi $26 \%$, a na održavanje i manje popravke $10 \%$. U nastavku ćemo pokušati malo izravnije povezati političku korupciju i javne kapitalne projekte u Hrvatskoj.

2002. 2003. 2004. 2005. 2006.

\begin{tabular}{|c|c|c|c|c|c|}
\hline Zgrade & 4,5 & 5,8 & 6,6 & 7,5 & 9,6 \\
\hline Stambene & 1,5 & 2,0 & 2,4 & 2,8 & 3,5 \\
\hline Nestambene & 3,0 & 3,8 & 4,2 & 4,7 & 6,1 \\
\hline Ostale građevine & 7,0 & 10,4 & 10,3 & 10,3 & 11,8 \\
\hline Prometna infrastruktura & 5,5 & 8,3 & 8,0 & 7,7 & 8,5 \\
\hline Cjevovodi, komunikacijski i energetski vodovi & 1,3 & 1,7 & 2,0 & 2,2 & 3,0 \\
\hline Složene industrijske građevine & 0,1 & 0,2 & 0,1 & 0,2 & 0,2 \\
\hline Ostale nespomenute građevine & 0,1 & 0,2 & 0,2 & 0,2 & 0,1 \\
\hline Ukupno & 11,5 & 16,2 & 16,9 & 17,8 & 21,4 \\
\hline
\end{tabular}

Izvor: DZS (2008.)

\section{Politička korupcija i javni kapitalni projekti}

Koliko je u Hrvatskoj prisutan utjecaj političke korupcije na javne kapitalne projekte? Za neke projekte nije najjasnije jesu li i koliko ekonomski opravdani. Na popisu su "sumnjivaca" za "katedrale u pustinji", primjerice, Pelješki most, ali tu su i nove rukometne dvorane, nedovršeni stadion u Maksimiru, nedovršena Sveučilišna bolnica u Zagrebu itd. Upitno je i koliko su isplative pojedine dionice autocesta. Uz kapitalne projekte učestalo su vezane afere koje upućuju na korupciju, ali većih sankcija dosad nije bilo. ${ }^{9}$ Poznato je sljedeće:

- troškovi gradnje u projektima gdje je država investitor često premašuju planirane

- $\quad$ ne izrađuju se dovoljno kvalitetne analize troškova i koristi

- $\quad$ postoje nepravilnosti u javnoj nabavi na svim razinama vlasti, često povezane s građevinskim poslovima, ali se $u$ tom smislu ništa ne poduzima

- $\quad$ stječe se dojam kako su određene građevinske tvrtke u povlaštenom položaju10

- postoji velika netransparentnost u donošenju prostornih planova, što se vezuje uz sektor građevinarstva

- nadzor nad lokalnim proračunima nije dovoljan, a iz njih nekoliko milijardi kuna godišnje odlazi na građevinske objekte

- uloga države kao investitora u sektoru građevinarstva velika je.

Uza sve to, stanje je sadašnje infrastrukture (vodoopskrba, električna energija, sustav odvodnje, cestovna i željeznič- 
DRUŠ. ISTRAŽ. ZAGREB GOD. 20 (2011), BR. 2 (112),

STR. $295-316$

BAĐUN, $M$ ODNOS POLITIČKE...

- TABLICA 7 Koruptivna kaznena diela od 2002. do 2007. godine došlo i analizom stanja bolnica, škola itd. Naravno, za stanje postojeće infrastrukture nije kriva isključivo korumpiranost dužnosnika, ali očito je da postoji veća sklonost $\mathrm{k}$ novim projektima nego održavanju postojećih, možda i zbog potencijalno većega mita. Zapravo su zbog desetljeća lošeg održavanja potrebne dodatne investicije u postojeću infrastrukturu, ali stječe se dojam da u Hrvatskoj prednost imaju lako vidljivi projekti, poput autocesta, mostova i sl., dok se zanemaruje ono što je ispod zemlje (vodovodna mreža, kanalizacijski sustav) i/ili što nije toliko "zanimljivo" građevinskom sektoru, poput željeznica, dalekovoda i sl. Naravno, vjerojatno ni održavanje nije lišeno korupcije, ali tu se iz političke sfere prelazi $\mathrm{u}$ administrativnu korupciju.

Europska komisija u svojem je izvješću za Hrvatsku naglasila kako se politička korupcija praktički ne istražuje (European Commission, 2009.), dok je Svjetska banka još 2004. godine navela da Hrvatska ne odudara mnogo od ostalih tranzicijskih zemalja kad je u pitanju administrativna korupcija, ali da zato ima visok stupanj političke korupcije (World Bank, 2004.). Nažalost, podataka koji se odnose samo na političku korupciju nema. U Tablici 7 vidi se da su od 2002. do 2007. godine za koruptivna kaznena djela bile osuđene 774 osobe, što bi u prosjeku bilo oko 130 osoba u godini. Oko $90 \%$ prijavljenih osoba odnosi se na zlouporabu položaja i ovlasti (čl. 337 Kaznenoga zakona). Ukupno ih je iz tog razloga u promatranom razdoblju bilo osuđeno 489, od čega je 110 dobilo bezuvjetnu zatvorsku kaznu. Od svih koruptivnih djela samo je u 144 slučaja oduzeta imovina.

\begin{tabular}{lccc}
\hline & Prijavljene osobe & Optužene osobe & Osuđene osobe \\
\hline 2002. & 872 & 295 & 111 \\
2003. & 1195 & 292 & 129 \\
2004. & 1287 & 346 & 121 \\
2005. & 1018 & 352 & 108 \\
2006. & 1320 & 421 & 137 \\
2007. & 1326 & 429 & 168 \\
Ukupno & 7018 & 2135 & 774 \\
\hline
\end{tabular}

Izvor: DZS (2009.)

\section{ZAKLJUČAK}

Ekonomisti često znaju hvaliti zemlje u kojima raste udio kapitalnih rashoda u ukupnim državnim rashodima. Isto tako, prihvatljivo se zadužiti za nove projekte, primjerice autoceste, ali ne i za održavanje sadašnje infrastrukture. No zbog korupcije neke javne investicije mogu negativno utjecati na ekonomski rast jer imaju nisku prosječnu produktivnost. Osim toga, 
DRUŠ. ISTRAŽ. ZAGREB BR. 2 (112),

STR. $295-316$

BADUN, M: ODNOŚ POLITIČKE... GOD. 20 (2011)

važno je i pitanje zaduženosti koju nove investicije izazivaju. Ovaj rad pokazuje da je za zemlje s visokim javnim investicijama karakteristična i raširena percepcija (političke) korupcije. Nameće se zaključak da bi u zemljama raširene korupcije ekonomisti trebali biti suzdržaniji u hvaljenju visokih javnih investicija.

Unatoč donedavno visokom udjelu javnih kapitalnih rashoda u BDP-u, Hrvatska ima infrastrukturu koja je u lošem stanju. Određeni postotak vrijednosti javnih kapitalnih projekata sigurno odlazi i na političku korupciju. Umjesto da političari priželjkuju rezanje vrpce za ostvarenje nekoga novog, vrlo vidljivog, investicijskog projekta, više bi pozornosti i novca trebali usmjeriti u održavanje i poboljšanje sadašnje infrastrukture, jer u Hrvatskoj milijarde kuna metaforički i doslovno otječu. Loša infrastruktura povećava trošak poslovanja i za državu i za privatni sektor te vodi do nižega ekonomskog rasta.

Usredotočenost na suzbijanje političke korupcije imala bi znatne učinke na racionalizaciju proračunskih rashoda kao i na ekonomski rast, pa bi težište primarno trebalo biti u borbi protiv visoke, a ne protiv sitne / lake korupcije. Pojačan nadzor nad potrošnjom lokalnih jedinica i detaljno istraživanje nepravilnosti koje bilježe Državni ured za reviziju i Državna komisija za kontrolu postupaka javne nabave bili bi dobar početak u toj borbi. Država bi pak projekte trebala birati na temelju izračuna troškova i koristi te službeno objavljivati završna odstupanja od tih izračuna. Osim toga, javnosti bi trebali biti dostupni ažurni i detaljni podaci o financijama javnoga sektora, što se osobito odnosi na javna poduzeća i proračune lokalnih jedinica.

\section{BILJEŠKE}

${ }_{1}^{1}$ Njihovo se istraživanje odnosilo na razdoblje od 1980. do 1995. te je pokrivalo do 95 zemalja, ovisno o raspoloživosti podataka. Koristili su se cross-country regresijama.

2 Vrijednost indeksa kreće se između 0 i 10, pri čemu 10 označuje nepostojanje korupcije. Što je indeks niži, to je raširenost korupcije veća.

3 U Eurostatovoj bazi podataka rabi se pojam javnih investicija, što je sinonim za bruto stjecanje fiksnoga kapitala opće države (general government gross fixed capital formation - GFCF). GFCF sastoji se od nabava rezidentnih proizvođača umanjenih za prodaju fiksne imovine tijekom određenog razdoblja i uvećanih za porast vrijednosti neproizvedene imovine, a koje stječu državni proizvođači ili jedinice kroz proizvodne djelatnosti (GFCF consists of resident producers' acquisitions, less disposals of fixed assets during a given period plus certain additions to the value of non-produced assets realized by the productive activity of government producer or units). Fiksnu imovinu čini materijalna i nematerijalna imovina koja je rezultat procesa proizvodnje te se i nju samu opetovano i kontinuirano rabi u procesima proizvod- 
DRUŠ. ISTRAŽ. ZAGREB GOD. 20 (2011),

STR. $295-316$

BAĐUN, $M$. ODNOS POLITIČKE... nje više od godinu dana (Fixed assets are tangible or intangible assets produced as outputs from processes of production that are themselves used repeatedly, or continuously, in processes of production for more than one year). Riječ bruto u nazivu može zbunjivati. GFCF zapravo pokazuje neto nove investicije $u$ fiksni kapital tijekom određenog razdoblja, obično godine dana. Riječ bruto u nazivu proizlazi iz toga što varijabla ne uzima u obzir smanjenje vrijednosti imovine (amortizaciju).

4 Održavanje uključuje redovito održavanje cesta i objekata, investicijsko održavanje cesta, betterment, održavanje zgrada i opreme, usluge HAK-a i Hidrometeorološkoga zavoda.

5 Opća država obuhvaća središnji proračun, izvanproračunske fondove te jedinice lokalne i područne (regionalne) samouprave. "Nefinancijska imovina prema metodologiji GFS-a 2001, jest sva ekonomska imovina osim financijske, tj. u nju nisu uključena potraživanja. Nefinancijska imovina obuhvaća proizvedenu imovinu (dugotrajnu imovinu - zgrade i građevine, postrojenja i opremu te ostalo; zalihe; pohranjene vrijednosti) i neproizvedenu imovinu (materijalnu imovinu prirodnog podrijetla nad kojom su nametnuta vlasnička prava - zemljište, rudna bogatstva i ostalu prirodnu imovinu te nematerijalnu neproizvedenu imovinu društvenog podrijetla - patente, koncesije, licencije, ostala prava itd.). Pri izvještavanju o ostvarenju državnog proračuna, kao i konsolidirane središnje i konsolidirane opće države, iskazuju se transakcije u nefinancijskoj imovini. Neto nabava nefinancijske imovine rezultat je iznosa transakcija koje povećavaju vrijednost imovine (nabave) umanjenog za iznos smanjenja imovine (prodaje)." (DZS, 2008., 229)

6 Iako se i Ministarstvo financija RH služi metodologijom GFS 2001, udio neto stjecanja nefinancijske imovine razlikuje se od onoga po podacima MMF-a. Za djelomično objašnjenje razlike vidjeti HNB (2007., 10-11).

7 Više o tome vidjeti u Bađun (2009.).

8 Vidjeti npr. članak objavljen 21. 7. 2009. u business.hr: "Birajući skuplje ponude HAC bacio 120 mil. kn" ili članak "USKOK istražuje HEP zbog štete od 130 milijuna eura" objavljen na portalu business.hr 20. 7. 2009. ili "Kalmeta - otac splitske tragedije", objavljen u Jutarnjem listu od 29. 7. 2009.

9 Primjeri za Grad Zagreb mogu se pronaći na ovoj internetskoj adresi: http://www.mutna.com/wp/?cat=18.

${ }_{10}$ Mito je lakše dobiti na tržištima gdje je konkurencija ograničena, kao što je to s velikim građevinskim poduzećima.

\section{LITERATURA}

Bađun, M. (2009.), Decentralizacija, korupcija i nadzor lokalnih proračuna u Hrvatskoj, Newsletter br. 38, Institut za javne financije.

Bajo, A. i Filipović, B. (2008.), Učinkovitost opskrbe vodom u Hrvatskoj, Newsletter br. 37, Institut za javne financije.

de la Croix, D. i Delavallade, C. (2009.), Growth, Public Investment and Corruption with Failing Institutions. Economics of Governance, 10 (3): 187-219. doi:10.1007/s10101-008-0057-4 
DRUŠ. ISTRAŽ. ZAGREB GOD. 20 (2011) BR. 2 (112),

STR. $295-316$

BAĐUN, M.: ODNOŚ POLITIČKE...
DKOM (2008.), Izvješće o radu Državne komisije za kontrolu postupaka javne nabave za 2007. http://www.dkom.hr/onama/GodisnjeIzvjesce 2007.pdf (21. 6. 2009.)

DORH (2009.), Izvješće o radu državnih odvjetništava u 2008. godini, Državno odvjetništvo Republike Hrvatske, http://www.dorh.hr/Godisnje IzvjesceO (28. 10. 2009.)

DZS (2008.), Statistički ljetopis 2008., Državni zavod za statistiku.

DZS (2009.), Koruptiona kaznena djela 2002.-2007., Državni zavod za statistiku.

European Commission (2008.), Croatia 2008 Progress Report, Brussels: Commission of the European Communities, 5. 11. 2008.

European Commission (2009.), Croatia 2009 Progress Report, Brussels: Commission of the European Communities, 14. 10. 2009.

Eurostat (2009.), Database, http://epp.eurostat.ec.europa.eu/portal/page/ portal/statistics/search_database (21. 6. 2009.)

Heidenheimer, A. J. i Johnston, M. (2002.), Political Corruption: Concepts and Contexts, New Jersey: Transaction Publishers.

HNB (2007.), Bilten. Tromjesečno izvješće, br. 127, Hrvatska narodna banka. HNB (2009.), Ekonomski indikatori. Hrvatska narodna banka, http://www. hnb.hr/statistika/hstatistika.htm (28. 10. 2009.)

Hrvatske vode (2009.), Strategija upravljanja vodama, http://www.voda. hr/fgs.axd?id=1344 (21. 6. 2009.)

IMF (2009.), Government Finance Statistics, International Monetary Fund.

Lambsdorff, J. G. (2007.), Institutional Economics of Corruption and Reform, New York: Cambridge University Press.

Mauro, P. (1995.), Corruption and Growth. The Quarterly Journal of Economics, 110 (3): 681-712. doi:10.2307/2946696

Mauro, P. (1998.), Corruption and the Composition of Government Expenditure. Journal of Public Economics, 69 (2): 263-279. doi:10.1016/ S0047-2727(98)00025-5

Mehrotra, A. i Välilä, T. (2006.), Public Investment in Europe: Evolution and Determinants in Perspective. Fiscal Studies, 27 (4): 443-471. doi:10.1111/j.1475-5890.2006.00042.x

Ministarstvo financija (2009.a), Godišnjak, različita izdanja, http://www. mfin.hr/hr/godisnjaci-ministarstva (21. 6. 2009.)

Ministarstvo financija (2009.b), Rebalans proračuna 2009., http://www. mfin.hr/hr/rebalans-proracuna-2009 (28. 10. 2009.)

Ministarstvo financija (2009.c), Lokalni proračun 2008., http://www. mfin.hr/hr/lokalni-proracun-2002 (28. 10. 2009.)

Narodne novine (2005.), Program građenja i održavanja javnih cesta za razdoblje od 2005. do 2008. godine, br. 3/05.

Narodne novine (2008.), Nacionalni program željezničke infrastrukture za razdoblje 2008. do 2012. godine, br. 31/08.

Rose-Ackerman, S. (1999.), Korupcija i vlada: Uzroci, posljedice i reforma, Zagreb: Progres. 
DRUŠ. ISTRAŽ. ZAGREB GOD. 20 (2011),

BR. 2 (112)

STR. $295-316$

BAĐUN, $M$. ODNOS POLITIČKE..
Tanzi, V. i Davoodi, H. (1997.), Corruption, Public Investment, and Growth, Working Paper No. 97/139, International Monetary Fund.

TI (2009.), Corruption Perceptions Index, Transparency International,

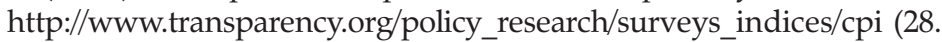
10. 2009.)

World Bank (2004.), Anticorruption in Transition 2: Corruption in Enterprise-State Interactions in Europe and Central Asia 1999-2002. The World Bank, Washington D.C.

World Bank (2009.), World Development Indicators, http://publications. worldbank.org/WDI/ (21. 6. 2009.)

\section{The Relationship between Political Corruption and Public Investment - The Case of Croatia}

\author{
Marijana BAĐUN \\ Institute of Public Finance, Zagreb
}

The goal of this paper is to show possible effects of political corruption on public investment, with special reference to Croatia. At the beginning of the paper the correlation between public investment and corruption in the EU countries is observed. Then the case of Croatia is analyzed, where quality of infrastructure, size of capital public expenditure, irregularities in public procurement, role of government in the construction sector, and effects of political corruption on public capital projects are considered. The paper shows that countries with high public investment have bigger (political) corruption. Despite the high share of public capital expenditure in GDP, Croatia's infrastructure is in a bad state. Judging by the size and the structure of public investment, as well as weak control mechanisms, there are plenty of opportunities for political corruption in Croatian public capital projects, for which there are strong indications that they are being used. Instead of investing in new, highly visible projects, policy makers should direct more attention and money towards maintaining and improving the existing infrastructure, because in Croatia billions of kunas are flowing away. Focusing on fighting political corruption would have significant effects on budget expenditure rationalization and economic growth.

Keywords: corruption, public investment, infrastructure, Croatia 
DRUŠ. ISTRAŽ. ZAGREB GOD. 20 (2011)

BR. $2(112)$

STR. $295-316$

BADUN, M.: ODNOS POLITIČKE..
Der Zusammenhang zwischen politischer Korrumpiertheit und öffentlichen Investitionen Der Fall Kroatien

Marijana BAĐUN

Institut für öffentliche Finanzen, Zagreb

Mit dieser Arbeit sollen, unter besonderer Berücksichtigung

Kroatiens, die möglichen Auswirkungen politischer Korrumpiertheit auf öffentliche Einrichtungen aufgezeigt werden. Die Verfasserin untersucht zunächst die Verbindung zwischen öffentlichen Investitionen und Korruption in den EU-Staaten. Dann geht sie auf den Fall Kroatien ein und untersucht die Qualität der öffentlichen Infrastruktur, die Höhe der öffentlichen Ausgaben, Irregularitäten bei der Vergabe öffentlicher Aufträge, das Eingreifen staatlicher Instanzen im Bereich des Bauwesens sowie die Auswirkungen politischer Korrumpiertheit auf öffentliche Kapitalprojekte. Die gewonnenen Einsichten zeigen, dass in Staaten mit einem hohen Anteil öffentlicher Investitionen auch mehr (politische) Korrumpiertheit vorliegt. Trotz des hohen Anteils öffentlicher Ausgaben am BNE befindet sich die Infrastruktur in Kroatien in einem schlechten Zustand. Im Hinblick auf Höhe und Struktur hiesiger öffentlicher Investitionen und die unzureichenden Kontrollmechanismen bieten sich im Bereich öffentlicher Kapitalprojekte reichlich Gelegenheiten für Korruption, die allem Anschein nach auch genutzt werden. Statt völlig neue Projekte in Angriff zu nehmen, sollten die Machtträger sich verstärkt der Instandhaltung und Verbesserung der bestehenden Infrastruktur widmen, denn die Beträge, die in Kroatien im übertragenen Sinne wie auch geradezu wörtlich aus dem Fenster geworfen werden, bewegen sich im Milliardenbereich. Würden sich die Behörden auf die Bekämpfung politischer Korruption fokussieren, hätte dies einen wesentlichen Einfluss auf die Rationalisierung staatlicher Ausgaben und das wirtschaftliche Wachstum des Landes.

Schlüsselbegriffe: Korruption, öffentliche Investitionen, Infrastruktur, Kroatien 